УДК $81 ` 0+81 ` 23$

https://doi.org/10.31548/philolog2020.02.038

\title{
THEORIES OF SPEECH DEVELOPMENT: FROM ANCIENT TIME TO THE PRESENT
}

\author{
O. S. POLISHCHUK, PhD in Philology, Associate Professor, \\ National University of Life and Environmental Sciences of Ukraine \\ E-mail: oleksandr_polishchuk@ukr.net \\ http://orcid.org/0000-0001-9306-617X
}

\begin{abstract}
Speech is the main mean of mediating higher mental functions. Several theories explain how a child learns to communicate.

Currently, the research approach in the study of the formation of human speech has changed. The focus of the study has shifted to the study of local phenomena and the relationship between theoretical approaches.
\end{abstract}

The purpose of research is to analyse the theories of speech development. In order to do this, we need to move in time and talk about the period from the middle to the end of the 20th century.

Results of research. There was a strife between global approaches that tried to explain the formation of human speech through the capture of real information by some innate structures designed to build speech that exist in the human nervous system even before he learned to speak.

Another major approach dealt with the tries to find those opportunities that a child has during development that would explain the occurrence of speech.

Now, the focus of the study of speech has shifted from attempts to explain the existence of speech in general to the study of more local events in the course of speech development. Moreover, global theories exist at the background level.

There are a number of researchers, who still adhere to Chomsky's ideas about the development of speech. Many researchers who are in a broader social-cognitive, social-functional paradigm.

Some researchers who do not talk about the specificity of speech development. They just explain this process by innate general cognitive mechanisms. The struggle occurs between those who generally explain the development of speech by cognitive processes and those who understands the development of communication as the development of speech, the development of social interactions between people and the emergence of speech as one of the means for social interaction.

We can see quite interesting clashes between these factions. For example, one of the reasons is the phenomenon of mutual exclusivity, regarding interesting data on how the acquiring of a new word occurs for the first time, upon its first presentation.

When this phenomenon was discovered it turned out that a number of authors immediately decided that this was a vivid manifestation of the fact that the child has a perception of the communicative system as a whole. The child relies on the same representation of the communicative system of another person. It automatically draws conclusions about the existence of such a communicative system. Such a learning situation is specific for a language.

On the other hand, authors who appeal to the processes of attention and memory always try to explain the data obtained by representatives of the socio-functional approach through the inevitably appearing emphasis that another person makes on the object.

Therefore, this struggle continues to this day, and the whole interest is in what formulation, to which model it will ultimately lead us.

Keywords: language, speech, speech acquisition, speech development, theory of interactionism, theory of cognitive development, universal grammar.

(C) O. S. Polishchuk

«International journal of philology» | «Міжнародний філологічний часопис» Vol. 11, № 2, 2020 
Introduction. People always wanted to know how a language is born in a person. And how to conduct linguistic experiments, especially if you have power and subjects?

You need to lock babies somewhere and wait. Herodotus wrote about this in his «History» [7]. The ancient Egyptian pharaoh Psammetikh locked two babies in a cave and ordered to serve them silently. At the age of two, they said a word similar to the Phrygian «bekos» (bread). This was the end of the experiment, because the pharaoh was informed that the Phrygians, as it turned out, were more ancient than Egyptians. However, it is extremely likely that nannies simply did not understand the babble of babies.

Much later, in the XIII century a similar experiment was conducted at the court of the Holy Roman Emperor Frederick II. The emperor was very educated, knew many languages, arranged mathematical competitions and encouraged autopsy for the benefit of science.

He ordered the women to take six babies, bathe them, look after them, groom them in every way, but not talk to them or even show any emotions. All this was made in order to find out what language the Lord gave Adam and Eve - Hebrew, Greek, Latin, Arabic, etc. This experiment was recorded "Chronicles» by the Franciscan monk Salimbene of Parma. He told us about the sad result of the experiment - all six babies died. Obviously, sleeping, warm water and feeding are not enough for babies.

A little over two centuries after the experiment of Frederick, and the story repeated itself. In the north of England, the king of Scotland, Jacob IV, wanted to determine whether the language is learnt or it just exists in a person since the birth. $\mathrm{He}$ sent two children and their mute nanny to Inchkit Island into a linguistic exile. The king was soon informed that the children mumbled in Hebrew, but we can hardly believe this story.

As we see, the first studies were carried out in conditions of evil irony - in order to understand how language appears, someone was deprived of it. But the first paths were laid, and in the twentieth century new theories of language acquisition appeared.

Recent researches and publications. There are four main theories of speech in modern linguistics: the theory of learning, the theory of preformism, relativistic theory and cognitive theory. The main controversy in these theories is whether speech is common to all mankind due to innate structures or it is an acquired structure, different in different cultures.

The theory of learning is represented by a behavioral approach (Watson, Mourea, etc.). This theory states that speech acquisition occurs consistently under the influence of the social environment.

The theory of preformism (Chomsky, Lenneberg, etc.) is based on the fact that a person since birth has specific inclinations to learn speech

The relativistic theory (Sapir, Wharf, etc.) states that each culture has its own language structure, which serves as a matrix for human thinking.

Cognitive theory (Piaget, etc.) states that the development of speech is associated with the inherent ability to perceive and process information.

The purpose of this study is to clarify what underlies the development of speech, what are the approaches to this problem, as well as an overview and summarizing of various theories of speech development.

Speech is the expression of thoughts and feelings by humans through articulated sounds that come out of our mouths and noses (with help from our cranial nerves, lungs, vocal chords, throats, soft palates, teeth, facial and neck muscles and tongues). Speech is one way that we express language. Despite the fact that people speak the same language, depending on the age, the specifics of the activity and environment, human speech acquires certain features.

To achieve the objective of the research, a number of general scientific methods (deduction, induction, analysis, and synthesis) were used.

American psychologist Burrhus Skinner [12] believed that any behaviour is determined by experience which is brought to 
automatism. If we do something and this activity has positive consequences, we will continue to do so. Language therefore is acquired through imitation, stimulation, and interaction.

But here there are objections. Firstly, children often make up phrases they never heard. Secondly, they recognize more words than they can use. Thirdly, children do not always respond to corrections, and they are not always corrected. Fourth, in different countries and in different languages, children go through the same stages of babble.

Jean Piaget claimed that children actively explore the world around them and use the environment and social interaction to form a language. Children need certain intellectual abilities to master specific aspects of speech. During the first year of life, children are not aware of the existence of objects outside their field of vision. At about 1.5 years of age, children begin to guess that objects may exist irrespective of their perception. In the same period, we observe a sharp increase in vocabulary, which means that these two phenomena are not only related, but the second follows from the first.

But there are facts about children who have mastered the language, despite nonstandard mental abilities. And the development, for example, of syntax does not rely so much on the general intellectual growth of a person.

There are several cultures in the world (in particular, Samoa and Papua New Guinea) in which they do not speak with a child until it itself begins to utter more or less articulate words.

But in most countries parents begin to talk nonstop with the child and even adapt to its speech, changing their own - this style was originally called «motherese» (mother's language). However, soon it became clear that this was not only done by mothers; therefore, this method of communication was called neutrally «baby talk» or scientifically «child-directed speech» (CDS).

Studies have shown that, compared to mother's speech, father's speech is more demanding, it has a wider vocabulary and more direct questions. The main goals of the CDS are:

1. to attract and hold the attention of the child;

2. to help with the breakdown of the language into easier to understand portions;

3. to make communication with the child more predictable, referring to the situation in the present tense. CDS:

Here are some tips for recognizing

- signs of secondary articulation, such as labialization;

- excessive intonation, high tone;

- repetition;

- speech is slower, cut into short parts, simplified (declination is less common, vocabulary is limited);

- reduplication («ding-dong») and diminutive words («doggy»);

- frequent imperative («say, show»);

- function words are omitted

- often a proper name is used instead of pronouns («Mummy loves you» instead of «l love you»);

- many questions to the child and paraphrasing of its answers.

The experts have no consensus on this way of communicating with children. Someone believes that CDS makes language learning more accessible, someone believes that CDS helps to keep the child's attention. American linguists Catherine Snow and Charles Ferguson have conducted a series of studies in 1977, which showed that the communicative behaviour of parents is the most important factor affecting the development of the speech. In fact, there is no convincing evidence that CDS helps a child go through all stages of language development faster. On the other hand, it is difficult to deny that slow and clear speech, especially in the early months of a child's life, helps to learn new words better.

To defend his theory of universal grammar, Noam Chomsky [4] spoke of the

(C) O. S. Polishchuk

«International journal of philology» | «Міжнародний філологічний часопис» Vol. 11, № 2, 2020 
linguistic poverty of adult speech, which he refers to the child (children's language instead of real adult speech), and therefore there is no special meaning in such children's language.

One of the cornerstones of universal grammar is the presence of a special innate language module in the human brain. In other words, the ability to absorb language is biologically programmed in us. This mechanism Chomsky called the Language Acquisition Device («device for the perception of language»), which encodes the basic principles of the language and its grammatical structures in the brain of a child. Children should only study the new vocabulary that comes from outside and apply the mentioned structures from LAD. This does not mean that a child can be born with excellent knowledge of Hindi or Swahili. When we are born, we do not have knowledge of the rules, sounds, or vocabulary of a particular language, all of which we must learn. But children do not need to figure out how the language works - what words we can build, what sentences to make, etc. These fundamental principles determine what is possible in human language and what is not. And this is true for all languages! Given how many of them are on the planet, it seems strange that there is only one set of principles «to rule everyone», so Noam Chomsky's theory has become truly revolutionary.

Chomsky cited the following arguments. Firstly, children go through the same stages of speech acquisition, regardless of language. Secondly, children learn a language much faster than adults. To move on such an accelerated schedule, they definitely need some kind of support from the inside. Let's look at babble. Regardless of the language being mastered, children use the same set of sounds. One study tested the babble of children from 15 different languages, including English, Thai, and Arabic - in other words, languages from different families. The study showed that all children tended to use consonants like [p] and [b]. They also preferred low vowels (for example [æ] and [a]) over high (for example [i] and [u]).
It's seems logical, because the child needs to be prepared for any language, therefore its articulation apparatus is «tuned» so as to accept any language of the world. And here we talk not only about sounds. Children also pick up words in the same "doses» and at the same stages without reference to a specific language. The way of mastering new sounds is the same all over the world - in London, Paris, or Denwer.

If we assume that the child copes with the language only through learning (without any mechanisms and programming in the brain), then computer simulation should cope with such a task quite simply. That is what the American linguist Lisa Pearl tried to check in 2011. She made 20 different computer models of how the stress system of English can be learned (for example, what syllables are pronounced stronger than others and what factors influence on this). And the experiment was conducted not only once, but as many as a thousand times for each model. The study showed that only three out of twenty thousand models coped with English. But children cope with it easily [10].

In 1977, Jacqueline Sachs and Barbara Bard published a study [11] of Jim whose parents were deaf but he could hear. Jim's parents wanted their son to learn to speak, rather than using sign language like them. He watched a lot of TV and listened to radio broadcasts, thus receiving a constant linguistic impact. However, his progress was limited until a speech therapist took care of him. As it turned out, one language impact was not enough because without communication and interaction there is an insuperable limit in language acquisition.

One of the most famous experiments in linguistics was conducted by the American psycholinguist Gene Berko Gleason. In 1958, she offered American children aged 4 to 7 to answer questions that used fictitious words, for example, «wug» or «zib». First, she showed a child a fictional creature and said "this is a wug».

Then she showed several of these creatures and said: «Now there are two of 
them. Two ...» and at this pause the children were asked to finish the sentence. All children correctly determined the plural of a noun that they had never heard before (and did not even know that it was a noun) - «wugs». That is, the children did not get the word they knew from their memory, but applied a rule that no one explained to them (but which seemed to be familiar to them). This test was repeated not only on nouns (children also successfully «guessed» the fictitious verb "spowed» or adjectives) and not only in English. The «Wug test» touched upon a huge number of phonological and morphological phenomena and made us to believe that children really have some kind of innate understanding of morphology [1].

Eric Lenneberg in 1967 put forward a hypothesis of a critical period [8]. He declared that without social development in the early years, language development could be severely limited. In other words there is a certain critical period that begins about at two years of age and ends at the end of puberty. During this period, it is necessary to determine about the first language. This theory especially fits in the context of the story of Genie Wiley [5].

In 1970, during a routine visit to a house in Los Angeles, a social worker paid attention to the strange behaviour of a girl of about seven years old, who acted like Mowgli. When a social service officer found out that the girl was actually 13 years old, he immediately reported to the local sheriff.

So Genie Wiley left her prison house, in which she was kept by a sick father and an almost completely blind mother. She could not talk and could not stand straight. As it turned out, during the day father held her tied to a highchair, and at night he put on a straitjacket and put her in a cage. Whenever Genie made a noise, dad beat her. He also didn't talk to her - he just snarled at her and barked like a dog.

After the rescue, Genie went through years of rehabilitation, including speech rehabilitation and physiotherapy. In the end, she learned to walk and use the toilet, and a year after liberation she even started pronouncing two-word combinations, for example, «big teeth» and "two hand». Six months later, in January 1972, after classes with the linguist Susan Curtis, using two- and three-word combinations Genie began to tell about her imprisonment: «Father beat leg. Big stick. Genie cry». After a while, the girl even began to read simple words but it was the limit of her abilities.

Genie's case partially refuted Lenneberg's hypothesis, because she managed to develop her speech skills after the years of horror in which she grew up. On the other hand, even after four years of training, Genie stuck at the phase of "telegraphic speech», which is a characteristic of children at the age of about two years. She did not learn to ask questions and did not cope with English grammar, which was contrary to the statements of Chomsky.

Children learn to speak passing through the same phases, regardless of skin colour, country of residence and language of parents. It is important to remember that there are no strict boundaries between phases, there is no clear sequence and different phases can take a different period of time.

Language development begins with the assimilation of the sound system - with screaming and crying. He also develops sensitivity to the sound differences of his newfound language. Even these sounds play an important role in the development of speech. There is a theory that vowels later appear from crying, and consonants appear from vegetative sounds (eructation).

So, the child hears the difference between, for example, voiced [ba] and voiceless [pa]. This innate ability enables children to pronounce sounds that are either not important at all in their native language or play a minor role. By the way, a strange phenomenon is observed in all languages after mastering a «sound toolkit» children begin to simplify it by discarding the first or last consonants. For example, in English instead of the word «ball» they say «ba», «top» instead of «stop».

Then follows babbling. It may seem amusing to us, but for a child this is a new and difficult phase of building a dialogue. From birth to 1 month, babies produce mainly pleasure sounds, cries for assistance, and responses to the human voice [9]. 
Around 2 months, babies can distinguish between different speech sounds, and can make «goo»-ing sounds [9].

Around 3 months, babies begin (making elongated vowel sounds «0ooo» «aaaa»), and will respond vocally to speech of others. They continue to make predominantly vowel sounds [9].

Around 4 months, babies may vary their pitch, and imitate tones in adult speech [9].

Around 5 months, babies continue to experiment with sound, imitating some sounds made by adults [9].

Around 6 months, babies vary volume, pitch and rate. When infants are 6 months old, they are finally able to control the opening and closing of the vocal tract, and upon obtaining this ability, infants begin to distinguish between the different sounds of vowels and consonants. This age is often distinguished as the beginning of the canonical stage. During the canonical stage, the babbling involves reduplicated sounds containing alternations of vowels and consonants, for example, «baba» or «bobo» [14]. Reduplicated babbling (also known as canonical babbling) consists of repeated syllables consisting of consonant and a vowel such as «da da da da» or «ma ma ma ma» [14].

Around 7 months, babies can produce several sounds in one breath, and they also recognize different tones and inflections in other speakers [9].

Around 8 months, babies can repeat emphasized syllables [9]. They imitate gestures and tonal quality of adult speech. They also produce variegated babbling. Variegated babbles contain mixes of consonant vowel combinations such as «ka da by ba mi doy doy» [6]. Variegated babbling differs from reduplicated babbling in terms of the variation and complexity of syllables that are produced [15].

Around 9-10 months, babies can imitate non speech sounds, and speech-like sounds if they are in the child's repertoire of sounds [9]. Infant babbling begins to resemble the native language of a child. The final stage is known as conversational babbling, or the «jargon stage». Usually occurring by about ten months of age, the jargon stage is defined as «prelinguistic vocalizations in which infants use adult-like stress and intonation» [13]. The general structure of the syllables that they are producing is very closely related to the sounds of their native language and this form of babbling significantly predicts the form of early words [3].

Around 11 months, babies imitate inflections, rhythms, and expressions of speakers [9]. By 12 months, babies typically can speak one or more words. These words now refer to the entity which they name; they are used to gain attention or for a specific purpose [9]. Children continue to produce jargon babbles beyond their first words.

At about the age of 12 months a period of holophrastic speech (from gr. holos «whole» + phrasis "expression»). This is the time when a child using one word (sometimes invented or distorted beyond recognition) often describes much more complex concepts and phenomena. Children clearly prioritize communication and single out one word that is especially important for them.

It is interesting that a child does not have to be able to pronounce the sound correctly in order to correctly recognize it. In a study of Gene Berko Gleeson and Roger Brown in 1960 [2], the word "fish» was used, which the child for some reason pronounced as "fis». When Brown, in response, began to call the fish in the same way («fis»), the baby shook his head, like saying, "What is "fis»? What are you talking about?» In other words the perception of phonemes leaves behind their reproduction, so children do not hear mistakes in their speech, but can notice mistakes in someone else's speech.

At the age of 18 months, the holophrastic phase smoothly flows into a two-word phase. Around this time, you can observe the "explosion of vocabulary», when the number of new words in a child is growing rapidly. The number of words does not grow meaningless, because at the

(C) O. S. Polishchuk

«International journal of philology» | «Міжнародний філологічний часопис» Vol. 11, № 2, 2020 
same time, children begin to use more complex two-word constructions - (often noun + verb). e.g. "want cookie». In addition to constructions borrowed from the language of adults, children can create «their» grammar, in other words, such constructions that they could not hear from adults (for example, «daddy water», which means "daddy is wet»).

At about the age of two, children begin to master more complex syntactic constructions, adding to more words. At first, these attempts did not sound very confident and resemble telegraphic speech - «Pa gi mi milk». In English, for example, at the telegraph stage you will not see the attributes of the past tense - «-ed», the third person - «-s», the articles «a», «the», and so on. To be brief, everything that is not considered important for transmission of thoughts remains inside the child's head.

During several months, the child gets acquainted with conjugation, prepositions etc. Interestingly, the children "telegraph» in different ways, depending on the region. For example, English-speaking child will ask to give an apple like this: "Give apple,» and not "Apple give,» like Japanese and Turkish child. Telegraphic speech using two- or three-word constructions lasts up to about 3 years. Around the three-year anniversary, more complex constructions

\section{References}

1. Berko, G. (1958). The Child's Learning of English Morphology. WORD, 14 (2-3): 150177. doi:10.1080/00437956.1958.11659661. hdl:11858/00-001M-0000-002A-5DDD-2. [in English].

2. Brown, R., \& Berko, G. (1960). Word Association and the Acquisition of Grammar. Child Development, 31 (1), 1-14. [in English].

3. Cheek, A., Cormier, K., Repp, A., \& Meier, R. P. (2001). Prelinguistic gesture predicts mastery and error in the production of early signs. Language, 77 (2), 292-323. [in English].

4. Chomsky, N. (1986). Knowledge of language. Its nature, origin and use. Westport: Praeger Publishers. [in English]. with subordinate sentences can already be observed in the children's speech.

At the age of about 2.5 years, the baby absorbs about 10 words per day, which is enough for building a vocabulary of 700 words. At the age of three years children use plurals and prepositions. At the age of four years, sentences become more complicated, vocabulary has about 1700 words, conjunctions are more common and child copes with sibilants. At the age of about 6 the child's vocabulary is nearly 3000 words.

Conclusion. It is important to realize that for the development of speech, there must be sufficient linguistic impact and a normal psychological atmosphere in the family. The children's brain works much better than it seems to us and can easily cope with two (or even more) languages, especially if they are presented in a relaxed environment. Of course, our world is not ideal and studying one, two or even three languages will not necessarily teach us how to understand other people.

So, it is clear that the problem of speech acquisition and speech develop-ment is far from its solution. This area of linguistics is vast and deep hence it requires further investigation. And results of this study can be used for sequential research and designing a general theory of speech development.

5. Donaldson, J. S. (2008, May 15). $S$ Wild Child Speechless After Tortured Life. ABCNEWS. Retrieved from https://abcnews. go.com/Health/story?id=48 04490\&page $=1$. [in English].

6. Harley, T. A. (1995). The Psychology of Language. UK: Erlbaum (UK) Taylor and Francis. pp. 352-354. [in English].

7. Herodotus (1987). The History. Translated by David Gren. Chicago: University of Chicago Press. [in English].

8. Lenneberg, E. H. (1967). Biological Foundations of Language. New York: Wiley. [in English].

9. Owens, R. E. (2005). Language Development: An Introduction. Boston: Pearson. [in English]. 
10. Pearl, L., \& Sprouse, J. Syntactic islands and learning biases: Combining experimental syntax and computational modeling to investigate the language acquisition problem. Language Acquisition, 20 (1), 23-68. [in English].

11. Sachs, J., Bard, B., \& Johnson, M. (1981). Language learning with restricted input: Case studies of two hearing children of deaf parents. Applied Psycholinguistics, 2(1), 33-54. [in English].

12. Skinner, B. F. (1957). Verbal Behavior. Michigan: Appleton-CenturyCrofts. [in English].
13. Sroufe, L. A., Cooper, R. G, \& DeHart, G. (1996). Child Development: Its Nature and Course. 3rd ed. New York: McGraw-Hill. [in English].

14. Waldron, Sh. (2007). The Significance of the Emergence of Language and Symbol in the Development of the Young Infant. Journal of Religion and Health, 46 (1), 85-98. [in English].

15. Werker, J. F., \& Tees, R. C. (1999). Influences on infant speech processing: Toward a new synthesis. Annual Review of Psychology, 50, 509-535. [in English].

\section{ТЕОРІЇ РОЗВИТКУ МОВЛЕННЯ: ВІД СТАРОДАВНІХ ЧАСІВ ДО НАШИХ ДНІВ О. С. Поліщук}

Анотація. Люди здатні робити дивовижні речі - кататися на велосипеді, ходити по Місяцю, складати музику, але сама дивовижна здатність - це мова. І ось що вражає. Як складно нам дається вивчення мови в зрілому віці і як просто з цим справляються діти - без особливих зусиль і потреби в формальній інструкції.

Проблема засвоєння мови завжди цікавила дослідників. Підходи до цієї проблеми були найрізноманітніші: біхевіористський підхід, теорія інтеракціонізму, теорія когнітивного розвитку, універсальна граматика і $m$. д.

Як і інші концепції, що стосуються поведінки, вони розходяться, зокрема, в питанні про те, чи є мова чисто людським надбанням, і якщо так, то чи можна вважати її структури універсальними і спадковими або ж це набуті структури, різні в різних культурах.

З іншого боку, багато суперечок пов'язані з тим, чи залежить розвиток мови від розвитку мислення, або, навпаки, мова є основою для розвитку пізнавальних фрункцій.

Зрозуміло, що проблема засвоєння мовлення та розвитку мовлення далека від ії вирішення. Ця область мовознавства $\epsilon$ широкою $i$ глибокою, тому потребує подальшого дослідження. Результати цього дослідження можуть бути використані для послідовних досліджень та розробки загальної теорії розвитку мовлення.

Ключові слова: мова, засвоєння мови, розвиток мови, теорія інтеракціонізму, теорія когнітивного розвитку, універсальна граматика.

(C) O. S. Polishchuk

«International journal of philology» | «Міжнародний філологічний часопис» Vol. 11, № 2, 2020 